\title{
Topical Emulsion Spray Dosage Form
}

National Cancer Institute

\section{Source}

National Cancer Institute. Topical Emulsion Spray Dosage Form. NCI Thesaurus. Code C149418.

Liquid preparation, usually multidose, consisting of an emulsion in a pressurized container with a spray valve or in a container equipped with a spray pump, intended for cutaneous use. 